\title{
「涼しさ」を感じる気流に関する屋外での実測とその解析 AN ANALYSIS ON THE OUTDOOR AIR MOVEMENT PROVIDING WITH 'SUZUSISA' SENSATION
}

\author{
斉藤雅也*，宿谷昌則** \\ Masaya SAITO and Masanori SHUKUYA
}

\begin{abstract}
This paper describes the relationship between 'suzusisa' sensation and the variation of air velocity obtained from the field measurement with subjective experiment. A female adult participated in the experiment as the subject. 'Suzusisa' sensation is a thermal sensation which we may have in a hot and humid environment with some breeze; 'suzusisa' is a Japanese word which exactly indicates this sensation.

We found that the subject does not necessarily feel 'suzusisa' sensation as she is exposed to an environment in which the air movement is strong. It is possible to feel 'suzusisa' sensation even with a relatively small air velocity after she is exposed long enough to an environment in which the air movement is still. According to the Fourier analysis, the spectra of the air velocity during the periods in which she had 'suzusisa' sensation is larger than that during the periods in which she did not. Normalized air velocity obtained from the spectra, the amplitude of the normalized air velocity during the period in which the subject had 'suzusisa' sensation is twice that in which she did not. The characteristics of the wave of the normalized air velocity is to increase suddenly and then decrease exponentially; this is considered essential to provide with 'suzusisa' sensation.
\end{abstract}

Keywords : 'Suzusisa' Sensation, Air Velocity, Fourier Analysis, Wave

「涼しさ」、気流速度、フーリエ解析、波形

\section{1.はじ的に}

寺田は、1929年と1933年に著した随等の中で、『涼しいというの は温度の低いということとは意哧が違う。㗨いという前提があって、 それに特䅀な条件が加わって始めて涼しさが成立するのである』 ${ }^{11}$ 、 あるいはまた、『涼しさは暑さとつめたさとが適当なる時間的空間的 週期をもって交代する時に生ずる感覚である』2) と指摘し、『われわ れ日本人のいわゆる「涼しさ」はどうも日本の特産物ではないかとい う気がする』 2) と述べた。わが国の建楼には、寺田のいう「涼しさ」 が得られる工夫がもともとあったと考えられる。例えば、媣い軒や庇 は㕛の強い日射をうまく遮灌し、庭木があれば、木陰を抜けて室内に 入ってくる風は、在室者に「涼しさ」を与えることが期待できる3)。

しかしながら、特に1960年代以降、このような毣さを防ぎ「涼し さ」を得る工夫は、冷房機器によって取って代わられるようになっ た。冷房は一般に、室内空気温度を下げ、均一な室内熱環境をつくり だすものなので、寺田の指摘したような「涼しさ」を得ることは奞し く、むしろしばしば「冷房病」と呼ばれるような「冷たさ」や身体の 「だるさ」を感じることが少なくない4）5》。

等者らは、日本の風土にふさわしい夏の建築翼境を実現するために は、「冷たさ」がつくられる冷房ではなくて、「涼しさ」が得られる 「涼房」の技術を開発するべきだと考える6) 8)。「涼しさ」をもた
らす技術を開発するためには、まず寺田の指摘したような「涼しさ」 が、どのようなメカニズムでもたらされるのかを改めて明らかにする 必要がある。

暑さを和らけるための通風や人工気流の活用に関する研究は、これ までにも少なからずある。例えば、人工気候室内で、定速気流と周期

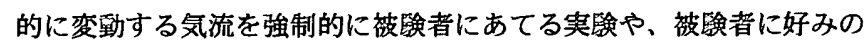
気流速度を選択させる㬰跧を行ない、被跧者がどのような温冾感覚や

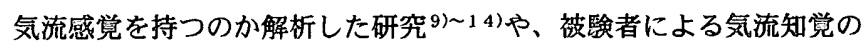
実験を屋外環境で行ない、快適感とSET の関係を求めた研究 ${ }^{15)}$ 、 室内環境で被䋡者が受ける「平均気流速度の大きさ」が気流の変動 感・速度感に大きな影㗽を与えることを示した研究 ${ }^{16)}$ などが挙げら れる。さらに通風とエアコンによる気流性状の違いに竡目した研究で は、室内環境で被跧者が気流を感知する時間幅 ${ }^{17)}$ や気流速度スペク トル18）19）を求めた例がある。

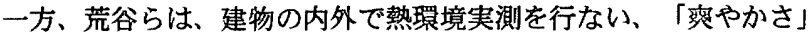
や「涼しさ」をもたらしているのは、空気温湿度や気流速度の微妙な 変化ではないかという孝察をするとともに、PMVのような一本化さ れた温冷感指徱では「涼しさ」を定量化することは難しいと指摘して いる20121)。久野らは「2 次元温冷感モデル」を提案し、「涼し い」や「暖かい」などの心理的反応の説明を試みている22)。また、

本論文は，1998年 9 月に行なわれた日本建築学会大会(九州)で発表した文献25)，26）修正・加籍したものである。

武蔵工藻大学大学院工学研究科建築学専攻

客員研究員 · 修士 (工学)

* 武蔵工業大学大学院工学研究科建築学専攻・環境情報学部 教授. 贡博
Visiting Scientist, Graduate School of Building Science, Musashi Institute of Technology, M. Eng.

Prof., Graduate School of Building Science, Faculty of Environmental and Information Studies, Musashi Institute of Technology, Dr. Eng. 
Bakerは、熱的ストレスが生じないようにするためには、定常的な中 立環境を冷暖房機器によって調整するのではなくて、建築的デザイン の工夫や居住者自身の住まい方を適度に調整することであると指摘し ている ${ }^{23)}$ 。しかしながら、寺田の指摘した「涼しさ」が、翼境を構 成する主たる物理量がどのような仕方で変化するときに生じるのかに 着目して行なった研究はこれまでにない。

本研究では、寺田の指摘した「涼しさ」を定量的に明らかにするた めに、夏季の屋外環境で被験者実測をおこなった。本報告では、「涼 しさ」が得られるときと得られないときの物理量の解析を行ない、特 に気流速度の波形の違いについて明らかにした結果を述べる。

\section{2. 実測概要}

実測は、武藏工業大学世田谷キャンパス内にある図書館前の道路上 で、1997年8月1日17:05〜17:35 と9月5日16:07〜16:37に行なった。 この図畫館前の道路は、4 階建て建物の東側を南北に走り、雨側に高 さ10mを越えるケヤキの枝葉が頭上を覆っている。実測両日は晴天で あったが、ケヤキの枝葉が十分な日射遮へい効果を発揮して、被験者 の体や路面には日射はほとんど入射しなかった。また、道路に沿って 風が断続的に吹いていた。したがって、この場所は「涼しさ」につい ての実測を行なうのにふさわしいと判断した。

被験者は、両日ともに健康な成年女子 1 名とした。被験者の服装 は、両日とも下着に加えて上半身が半袖フフラウス、下半身が膝丈程度 のスカートとした。着衣量は、8月1日が0.37clo、9月5日が0.42cloで あった。被験者は、全身もしくは身体のどこか一部でも「涼しさ」が 得られたときに口頭で「涼しい」と記録者に伝え、記録者はその時刻 を記録した。

被験者を 1 名に限定した理由は、次のとおりである。寺田のいう 「涼しさ」は、それを感じる人と感じない人がいるというものではな く、一人ひとりが「涼しさ」を感じるときがあったりなかったりとい うことである。「涼しさ」が得られているときと得られていないとき の双方が一人の被験者に存在するとすれば、䁲境を構成する物理要 素、特に気流速度の波形に相対的な違いがあって、それが「涼しさ」 を与えるか否かを決めるであろうと予想される。このことをまず被験 者一人について吟味したいと考えた。多数の被験者を対象にする研究 は、次の段階で行なう方がよいと判断した。

温熱環境に関わる物理量の測定は、写真に示すように、椅子にす わった被験者から $1 \mathrm{~m}$ 程度離れたところで、空気温度・グローブ温 度・相対湿度・気流速度を小型テータロカー（江藤電気・2100A)に 2 秒 間隔で連䌇計測した。空気温度とグローブ温度の測定は $0.2 \mathrm{~mm} \phi \mathrm{c}-\mathrm{c}$ 熱電対で、相対湿度は静電容量式の温湿度センサー(江藤電気 • 2119A)で測定した。気流速度は、予め実測開始前に主風向を確認し て、被験者が測定に影響を与えないような位置で、 $0.02 \mathrm{~m} / \mathrm{s}$ 程度の微 風速まで測定可能な微風速計(DANTEC・54R10 と54N50)を用いて測 定した。気流速度の瞬時的な変化を対象とするには、測定間隔が 2 秒 では粗すぎるかもしれない。しかし、本研究では「涼しさ」が得られ るときと得られないときの気流速度の大まかな波形を抽出することを 主たる目的としたので、2秒間隔でよいと判断した。

\section{3. 結果と考察}

\section{3-1.「涼しさ」と物理量}

図 1 は、8月 1 日の実測の最初の 5 分間（17:05〜17:10）における 空気温度・平均放射温度の経時変化と被験者の「涼しさ」申告を示し

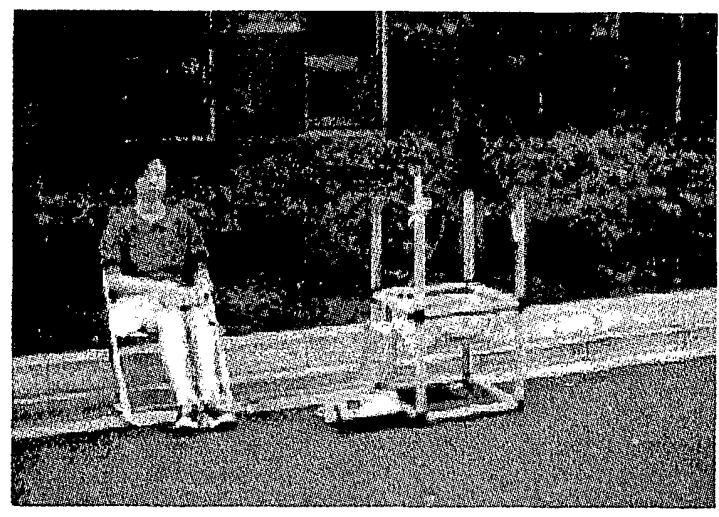

写真 実測風景（1997年9月5日16:00頃）

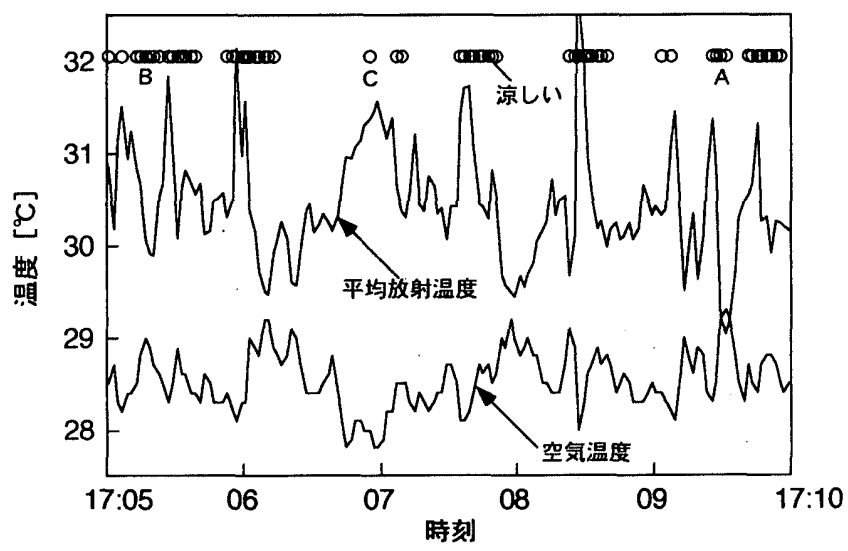

图 $18 / 1$ の空気温度・平均放射温度と「涼しさ」申告

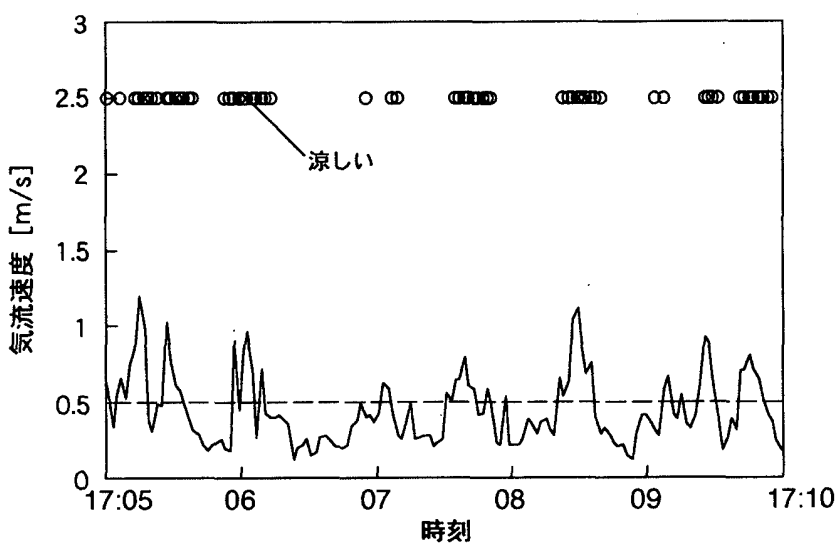

図 $28 / 1$ の気流速度と「涼しさ」申告

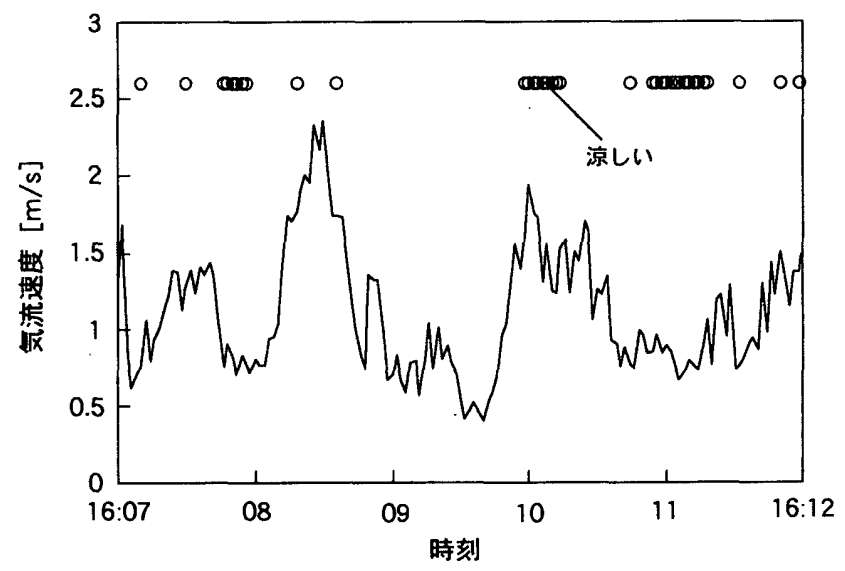

図 $39 / 5$ の気流速度と「涼しさ」申告 
たものである。空気温度は $28 \sim 29{ }^{\circ} \mathrm{C} 、$ 平均放射温度は $29.5 \sim 32.5^{\circ} \mathrm{C}$ 推移している。被験者やその周囲の地表面には、直達日射がほとんど 当たっていないので断続的に「涼しさ」が得られている。「涼しさ」の 申告は、図中のAやBのように、10秒から40秒間連続して得られる場合 もあれば、Cのように、ほとんど瞬間的に得られる場合もある。「涼し さ」の申告と、適度に摇らいでいる空気温度や平均放射温度の間には明 確な関係があるようには見えない。17:10〜17:35についても図 1の結 果と同様の傾向が見られた。相対湿度についても同様であった。相対湿 度は68〜69\%であった。

9月 5 日についても 8 月 1 日と同様に断䌇的に「涼しさ」は得られて いた。9月 5 日の空気温度は $27.5 \sim 28.5^{\circ}$ C、平均放射温度は $27 \sim 28.5$ C C、相対湿度は64〜68\%を推移していたが、空気温度、平均放射温度 や相対湿度の摇らざと「涼しさ」申告との間に相関があるかどうかはや はりわからなかった。

図 2 と図 3 は、8 月 1 日と 9 月 5 日のそれぞれ実測の最初の 5 分間に おける気流速度の経時変化と被験者の「涼しさ」申告を示したものであ る。 8 月 1 日は、気流速度が抒おむね $0.5 \mathrm{~m} / \mathrm{s}$ を超えている場合に、被 験者は「涼しさ」を感じている。一方、9月 5 日は、気流速度が 8 月 1 日よりも全般的に高い。しかし、気流速度がある値より大きいときに 「涼しさ」が得られるという 8 月 1 日で読みとれた傾向は見られない。 「涼しさ」が得られるためには $0.5 \mathrm{~m} / \mathrm{s}$ 程度以上の気流速度が必要であ るけれども、気流速度が $0.5 \mathrm{~m} / \mathrm{s}$ 以上あれば、ただちに「涼しさ」が得 られるわけではなさそうである。

図4 は、両日における気流速度ごとに「涼しさ」が得られた割合を示 したものである。綎軸は、ある気流速度において「涼しさ」が得られた 回数をその気流速度の実測値の個数で除したものである。 8 月 1 日は、 気流速度が0.5〜 1.5m/sの範囲で、9月 5 日は0.5〜 3.0m/sの範囲で それぞれ「涼しさ」が得られている。気流速度の值が大きければ大きい ほど、「涼しさ」が得られるということではないことがわかる。8月 1 日の平均気流速度は、9月 5 日のそれに比べて小さかったので、「涼し さ」は、平均気流速度の大きさだけではなくて、気流速度の増隇にある のではないかと推測できる。

図 5 は、気流速度の差と「涼しさ」が得られた回数の関係を示したも のである。気流速度の差とは、「涼しさ」が申告されたときの気流速度 の值から、その 2 秒前（計測データとして 1 個前）の気流速度を引いた 值である。この図は、差が正の值として出た場合、すなわち気流速度が 大きくなって「涼しさ」が得られた場合のみ示しているが、負の値で出 た場合も絶刘値を取れば、図 5 とほほ同様のかたちになった。両日とも

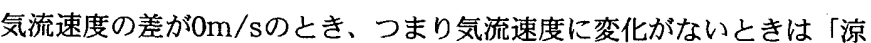

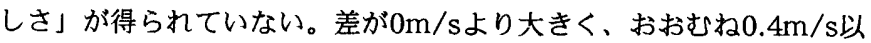
下のときに「涼しさ」が顕著に得られている。また、差が $0.5 \mathrm{~m} / \mathrm{s}$ 以上 では、「涼しさ」はあまり得られていない。

「涼しさ」を感じるには、「涼しさ」を感じ始めるまでの「涼しさ」 を感じていない時間の長さが関係しているのではないかと考え、8月 1 日について、「涼しさ」を感じていない時間の長さと、その時間経過の 後に「涼しさ」を感じ始めた時点での気流速度との関係を調べた。その 結果を図 6 に示す。「涼しさ」を感じていない時間が短いほど、「涼し さ」を得るには大きな気流速度が必要で、逆に時間が長いほど、比較的 小さな気流速度でも「涼しさ」を感じる傾向がみて取れる。

図 6 で明らかになった現象を人体内部での熱エネルギーの蓄積とその 放出する速さに着目して考察すると、暑熱環境下で「涼しさ」を感じて いない時間が長く続くときは、人体内部へ熱エネルギーが蓄積され続け

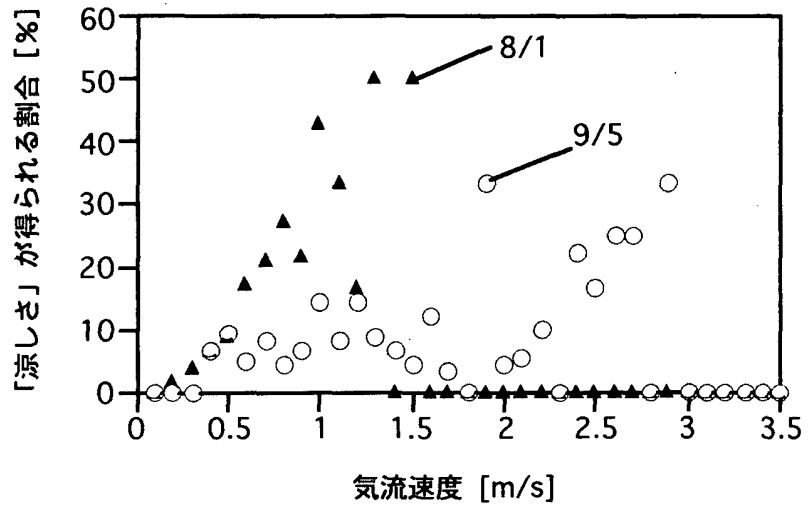

図4 各気流速度で「涼しさ」が得られる割合

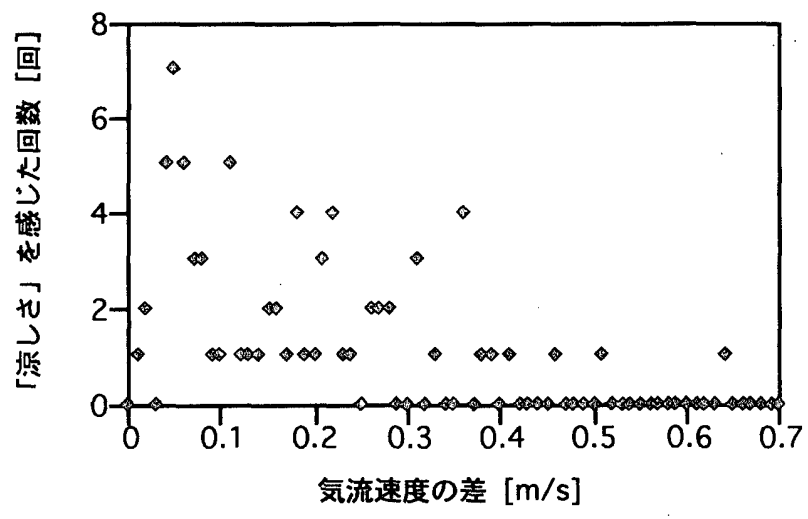

図5気流速度の差と「涼しさ」を感じた回数

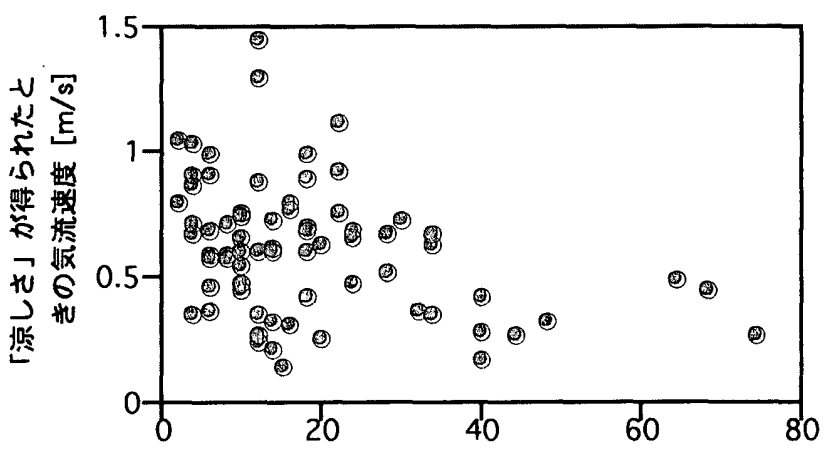

「涼しさ」を感じていない時間の長さ [s]

图6「涼しさ」を感じていない時間とその時間経過後に 「涼しさ」を感じたときの気流速度の大きさ

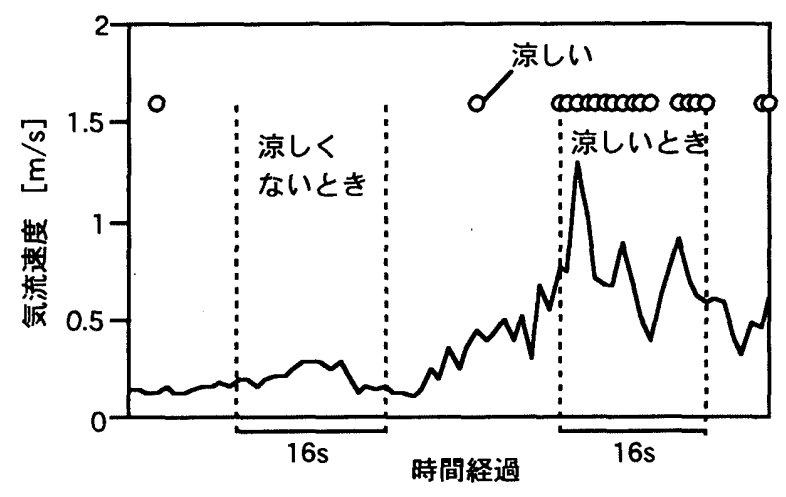

图 7 「涼しいとき」と「涼しくないとき」の気流速度 
て、かなりの量の熱エネルギーが人体に蓄えられていることになる。 このときは、「涼しさ」を感じていない時間が短いときより、皮佰表 面温度と周囲空気温度の差が比較的大きくなっていると考えることが できる。そのため、小さな気流速度でも、人体内部で蓄えられた熱工 ネルギーの放出する速さは大きいので、「涼しさ」を感じることがで きたのではないかと考えられる。逆に「涼しさ」を感じていない時間 が短ければ、人体内部での熱エネルギーの蓄䅡が小さく、皮居表面温 度と周囲空気温度の差はあまり大きくならず、「涼しさ」を感じるの には比較的大きな気流速度が必要になるということではないかと考え る。

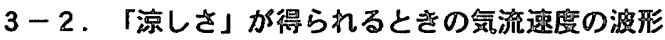

「涼しさ」が得られているときと得られていないときのそれぞれに ついて、気流速度の波形の違いを明らかにするためにフーリ工解析を おこなった。8月 1 日と 9 月 5 日の気流速度の経時変化から、図 7 に 示すような連䌇的に「涼しさ」が得られているとき（涼しいとき） と、連続的に「涼しさ」が得られていないとき（涼しくないとき）の 16秒間の気流速度データをそれぞれ16サンプルずつ抜き出した。実測 デー夕は 2 秒間隔なので、それが 2 秒間ずつ続いたとして 1 秒ごと 16 個 のデータを解析の対象とした。なお、1サンプルを16秒間ずつにした 理由は、両日とも、10〜20秒間の長さで「涼しさ」が得られているこ とが最も多かったことと、フーリエ変換によるスペクトルの算出は、 変換を行なう前の元のデータが $2^{n}$ 個あるときに可能なので、 $\mathrm{n}=4$ のと き、すなわち $16\left(=2^{4}\right)$ 個のデータを用いるのが妥当だと判断したから である。

フーリエ変換を行なう前に、「涼しいとき」と「涼しくないとき」 のそれぞれ16サンプルの乱れがどの程度なのかを計算した。サンプル それぞれの平均値と標準偏差值から、乱れの強さ（=標染偏差值/平 均值）を求めた。 8 月 1 日の「涼しいとき」と「涼しくないとき」の 乱れの強さの平均はそれぞれ 0.44 と0.05、9月 5 日はそれぞれ 0.14 と 0.08であった。「涼しいとき」の乱れの強さは、「涼しくないとき」 のそれに比べて大きい。

図 8 は、16サンプルずつ抜き出した「涼しいとき」と「涼しくない とき」の気流速度のデータを、フーリ工変換によって得たスペクトル 分布である。一つの周波酄に対して、「涼しいとき」と「涼しくない とき」のそれぞれについて16個のプロットがある。「涼しいとき」の 方が、「涼しくないとき」よりも周波薮ごとにおけるスペクトルの值 が大きい。これは、気流速度の波形が、異なる振幅をもつ $\cos$ 波と $\sin$ 波の足しあわせで表せることを考えると、「涼しいとき」の気流速度 を俩成している波の振幅が、「涼しくないとき」のそれに比べて大き いことを意味している。

図 8に示したスペクトルの違いからだけでは、「涼しさ」が得られ る気流速度の波形そのものを值接見ることはできない。また、8月 1 日と 9 月 5 日の両日において、「涼しいとき」の16サンプルと「涼し くないとき」の16サンプルはみな、気流速度の変動する䉇囲が異な る。そこで、波形を露わにし、「涼しいとき」と「涼しくないとき」 の気流速度の振幅や增減の仕方がどの程度違うのかについて定量的に 示したいと考え、「涼しいとき」と「涼しくないとき」の周波数ごと のスペクトルを用いて計算できる以下に示す式 $(1)$ のv $(t)$ の値を比較 することにした。

フーリエ変換によって得られた周波数ごとのスペクトル群は、変換 の対象とした気流速度を勒成する $\cos$ 波と $\sin$ 波の相対的な重みを表し

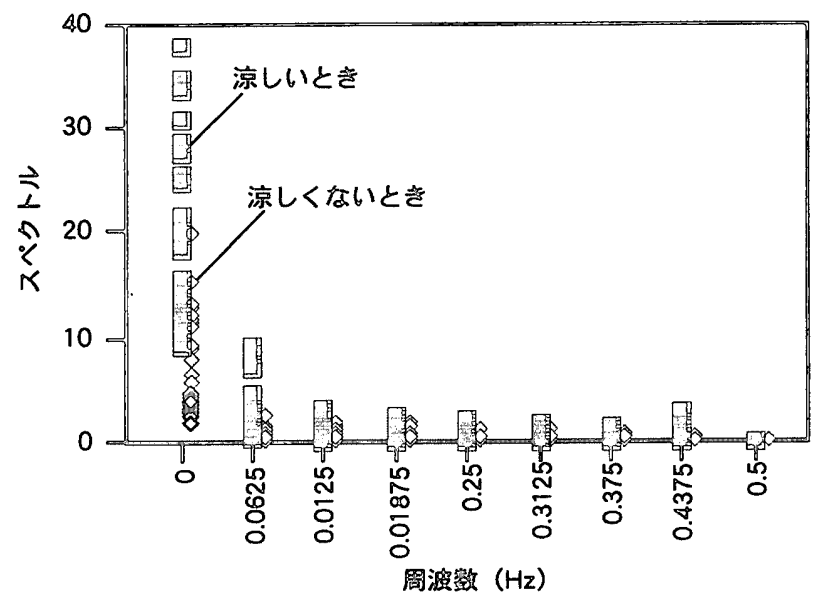

图 8 「涼しいとき」と「涼しく约いとき」のスペクトル分斾

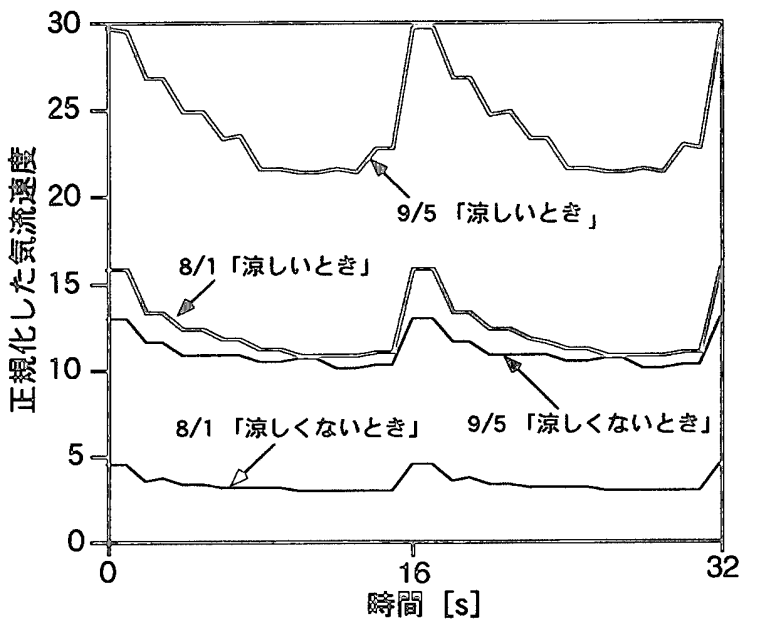

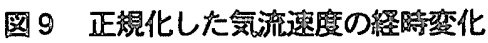

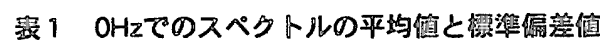

\begin{tabular}{|c|c|c|}
\hline & 平蚐值 & 徱準偏差值 \\
\hline 8/1「湶しいとき」 & LX2.08\% & 2.45 \\
\hline 8/1「湶しくないとを」 & 3.23 & 0.84 \\
\hline 9/5「源しいとき」 & 23.92 & 8.00 \\
\hline 9/5「湶しく灾いとき」 & 10.86 & 3.49 \\
\hline
\end{tabular}

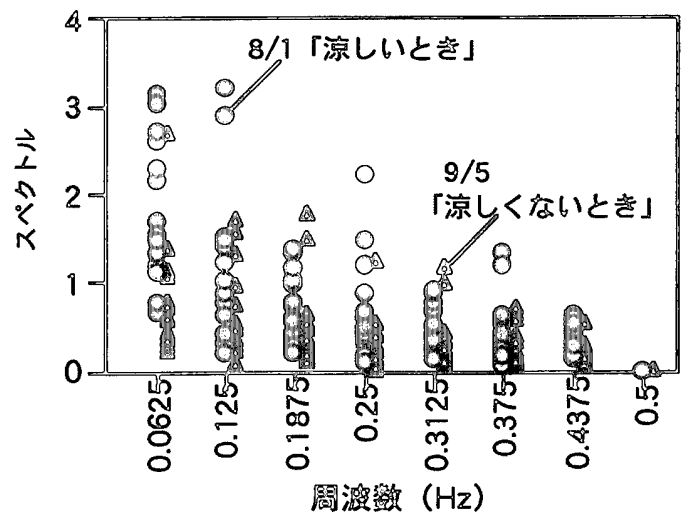

图 10 8/1「僦しいと部」と

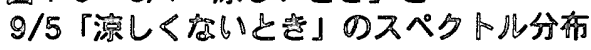


ている。したがって、 $v(t)$ の値は気流速度の実際の值を与えるもので はない。そこで、このv(t)の值を「正規化した気流速度」と呼ぶこと にする。

$$
\begin{gathered}
v(t)=a_{0}+\sum_{n=1}^{8}\left(a_{n} \cos n \omega t+b_{n} \sin n \omega t\right) \\
\omega=2 \pi f_{0}
\end{gathered}
$$

$a_{n}$ とb $b_{n}$ は、それぞれcos波とsin波の周波数ごとの振幅の大きさであ る。 $\omega$ は基本角速度、 $f_{0}$ は基本周波数。本研究では $f_{0}=1 / 16=$ $0.0625 \mathrm{~Hz}$ 。三角関数の合成より、式 (1) は、次式 (3) のように 書き換えることができる。

$$
\begin{gathered}
v(t)=a_{0}+\sum_{n=1}^{8} d_{n} \sin \left(n \omega t+\alpha_{n}\right) \\
d_{n}=\sqrt{a_{n}^{2}+b_{n}^{2}}
\end{gathered}
$$

ここで、

$$
\alpha_{n}=\tan ^{-1} \frac{a_{n}}{b_{n}}
$$

である。

図 8 に示した周波数ごとのスペクトルは、式（3）に現れる $a_{0}$ と $d_{n}$ である。 $a_{0}$ とd $d_{n}$ は「涼しいとき」と「涼しくないとき」のそれ ぞれ16サンプルごとに得られたので、その平均值を求め、その結果 を正規化した気流速度 $v(t)$ の計算に用いることにした。なお、式

（3）中の $\alpha_{n}$ は、正規化した気流速度 $v(t)$ の位相差であるが、この 値は、フーリエ変換からは直接得られない。 $v(t)$ の位相差 $\alpha_{n}$ の違い は、気流速度の振幅や増減の仕方に影響を与えないので、ここでは 正規化した気流速度 $v(t)$ の値を具体的に求めるために、 $a_{n}=b_{n}$ 、すな わち $\alpha_{n}=\pi / 4$ と仮定して計算を進めることにした。

図 9 は、図 8 の周波数ごとのスペクトル平均值を使って求めた 8 月 1 日と 9 月 5 日の「涼しいとき」と「涼しくないとき」のそれぞ れにおける正規化した気流速度である。横軸は時間を表し、フーリ 工変換に用いた 1 サンプルの時間の長さ（=16秒間）を 1 周期と考え たときの2周期分に相当する32秒間を示している。

9 月 5 日の「涼しいとき」の正規化した気流速度は、8月 1 日と 9 月 5 日の「涼しくないとき」のそれらよりも大きい。8月 1 日の 「涼しいとき」の正規化した気流速度は、9月5日の「涼しくない とき」のそれよりもやや大きい。表 1 は、これら4つの正規化した 気流速度の $0 \mathrm{~Hz}$ でのスペクトルの平均値（ $\mathrm{a}_{0}$ の平均値）と標準偏差值 を示したものである。 8 月 1 日の「涼しいとき」のスペクトル平均 値は12.03で、9月 5 日の「涼しくないとき」の10.86よりも約1.2 大きい。0Hzでのスペクトル平均值は、正規化した気流速度の中心 軸であるので、この差は正規化した気流速度の平均值としての差で ある。一方、図 9 で、8月 1 日の「涼しいとき」の正規化した気流 速度の振幅は 5 程度であるのに対し、9月 5 日の「涼しくないと き」の振幅は2.5程度で、その差は2.5である。この值は、 $0 \mathrm{~Hz}$ スペクトル平均値の差1.2よりも大きい。したがって、この振幅の大 きさが、「涼しさ」を与えるか否かに重要な役割を果たしていると 考えられる。

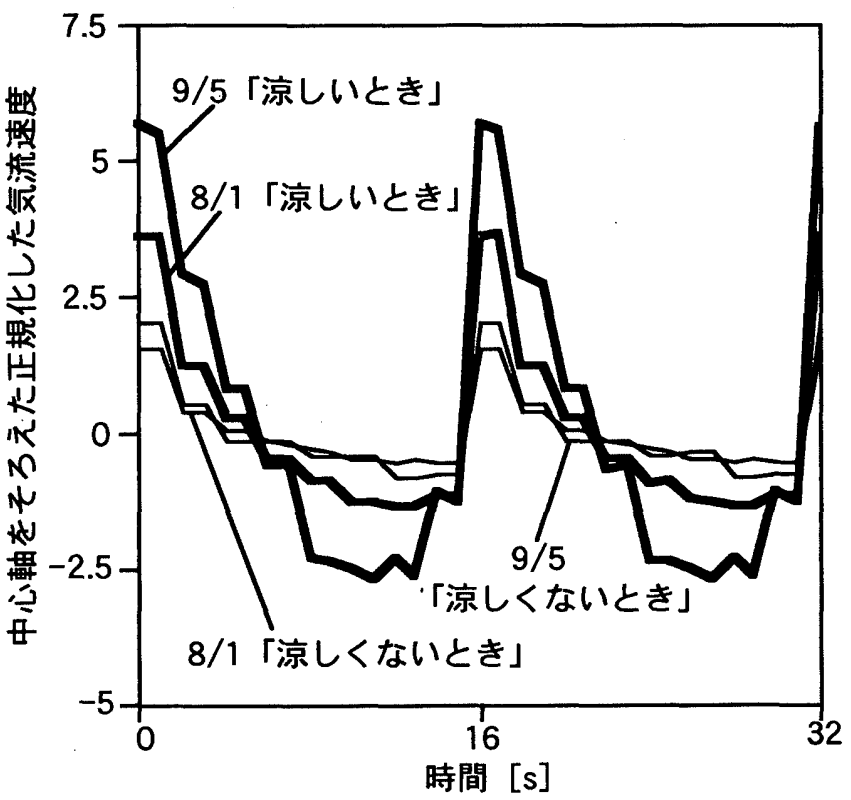

図 11 中心軸をそろえた正規化した気流速度 の経時变化

図 8 に示したスペクトルから、8月 1 日の「涼しいとき」のスペク トル、9月 5 日の「涼しくないとき」のスペクトルを、0.0625〜 $0.5 \mathrm{~Hz}$ について抜き出したものを図 10 に示す。 8 月 1 日の「涼しい とき」の方が、9月 5 日の「涼しくないとき」よりも全体的にスペク トルが大きい。

図 11 は、図 9 に示した正規化した気流速度から、表 1 に示した

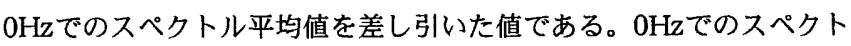
ル平均値を差し引いているので、縦軸は、正規化した気流速度の波の 中心軸をそろえたものとして表現されていることになる。8月 1 日、 9 月 5 日ともに、「涼しいとき」の方が「涼しくないとき」よりも、 正規化した気流速度の振幅が大きいことがわかる。振幅の差は、2 倍 以上ある。図 11 に示した正規化した気流速度の波形は、いずれも、 急激な上昇に引き続くゆっくりとした下降である。この変化の仕方が 大きいと、「涼しさ」が得られるといえる。これが、寺田の指摘した 「涼しさ」の特徽と考える。8月 1 日の「涼しいとき」の正規化した 気流速度と 9 月 5 日の「涼しくないとき」のそれとの間のどこかに、

「涼しさ」が得られるか得られないかの境界があると考えられる。

\section{4.まとめ}

「涼しさ」が得られる気流について夏季の屋外環境での被験者実測 と解析を行なった結果、以下のことが明らかになった。

1）「涼しさ」が得られるには、約 $0.5 \mathrm{~m} / \mathrm{s}$ 以上の気流速度が必要で あるけれども、気流速度が大きければ大きいほど得られるわけで はない。

2）気流速度の変化が2秒の間に $0.4 \mathrm{~m} / \mathrm{s}$ 以内であったときに「涼し さ」がよく得られる。変化が $0.4 \mathrm{~m} / \mathrm{s}$ 以上あっても「涼しさ」は あまり得られない。

3）「涼しさ」が得られていない時間が長いほど、比較的小さな気流 速度で「涼しさ」は得られ、逆に短いと、「涼しさ」が得られる のには大きな気流速度が必要である。 
4)「涼しさ」が得られているときの気流速度の乱れの強さは、「涼 しさ」が得られていないときのそれに比べて大きい。

5）「涼しさ」が連綍して得られるときの正規化した気流速度は、 「涼しさ」が得られないときのそれと比較して、振幅が 2 倍以 上大きく、波形の特徵は、急激な上昇に引き䌇くゆっくりとし た下降である。

今後、被験者数を增やしていくことで、「涼しさ」が得られるときの 気流速度の普遍的な波形を明らかにしていく必要があると考える。ま た、普遍的な波形が明らかになったとして、それが室内の所要の場所 で得られるような空の貶置・大きさや日除けがどのようなものなのか を明らかにしていくことも必要と考える。

\section{湢碚}

本研究は、当時、武蔵工業大学卒論生であった北條厚子氏（現、新日軽株式会 社）と䓫㙫倫実氏（現、相鉄不動産株式会社）の協力によって行なうことがで きました。ここに記して感謝の意を表します。

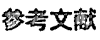

1）寺田宙彦：さまよえるユダヤ人の手記より、寺田宙彦全集第三巻（初出 「思想」1929年9月）、岩波蓄店、1997、pp.196-205。

2）寺田寅彦：涼味数題、寺田寅彦全集第三巻（初出「週間朝日」1933年8 月）、岩波書店、1997、pp.339-346。

3）小玉鿆一郎：住宅に㧍ける防箸・採涼の技術、IBEC、1983年6月、pp. 14-21。

4）大野秀夫：夏の涼しい暮らし、自然と住まいの環境（堀越哲美・澤地 孝男編）、彰国社、1997、pp. 75-87。

5）松岡弘幸・斉藤雅也・宿谷昌則：暑さへの対処方法が温冷感觉と冷房 用エクセルギー消费量に与える影喓、日本建筑学会大会 (九州) 学術譺 演梗概焦（環境工学II）、1998、pp. 457-458。

6）宿谷昌則：涼房について、日本住宅協会雑誌、1982、pp.68-71。

7) 木村建一：涼房、建築雑誌、Vol.102,No.1255、1987年1月、p.54。

8）宿谷昌則：自然共生建筑を求めてーその 12 、冷やすー、ライブエナー シ、No.53、1996、pp.12-17。

9）准田英樹 : 室内気流と体感、空気調和・衛生工学 第58卷 第3号、昭 和59年3月、pp. 33-38。

10）不村建一・田辺新一 - 原俊広・秋元孝之 ・秋山尚之 - 岩田利枝・田宮建 司・近岡正一：夏季の通風・室内気流が体感に及ぼす影塪に関する研究 （その 1 〜の 4 ）、日本建筑学会大会（近畿）学術講演梗概集（睘境 工学) 、昭和62年10月、pp. 335-342。

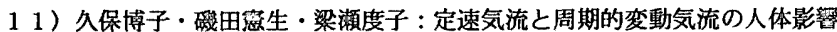
について、家政学研究報告集、Vol. 32, No. 1、1985年9月、pp. 98104 。

12 ）桑沢保夫・斉藤基之・鎆田元康・千田善孝 : 変動風の快適性に及ぼす影 艮に関する研究（その 7 定常風及び変動風の対流熱伝達率）、日本建築 学会大会 (北海道) 学術譜演梗概集（環境工学II）、1995年8月、pp. 375-376。

$13)$ H. Kubo, N. Isoda and H. Enomoto-Koshimizu : Cooling Effects of Preferred Air Velocity in Muggy Conditions, Building and Environment, Vol. 32, No. 3, 1997, pp. 211-218。

14 ) E. Arens, T. Xu, K. Miura, Z. Hui, M. Fountain and F. Bauman : A Study of Occupant Cooling by Personally Controlled Air Movement, Energy and Buildings 27, 1998, pp. 45-59。

$15 ）$ 石井明夫・片山忠久・塩月義隆・吉水久雅・安部嘉孝：屋外環境におけ る饥適感に関する実験的研究、日本建勧学会計画系論文報告集 第386 号、昭和63年4月、pp. 28-37。

16 ）梢原典子・石井昭夫・片山忠久・西田勝・堤能一郎：通風環境における 気流知覚に関する実领的研究、日本建築学会計画系論文報告集 第385 号、昭和 63 年 3 月、pp. $1-8$ 。

17）梅宮典子・松浦邦男 : 夏抙通風罢境における気流感知時間率の快適性許 価に及ほす寸影䍄、日本建築学会計画系論文報告集 第440号、1992年10 月. pp. 21-29。
18 ）梅宮典子・松浦邦男 : 夏李通風垶境における纼適性婹価と気流速度スペ クトルについて、日本建築学会計画系論文報告集 第461号、1994年7 月、pp. 51-59。

$19 ）$ 本村建一一田辺新一・川原井大・伊藤昭・桑沢保夫：夏季の通風・室内 気流が体感に及ぼす影繁に関する研究（その 5 ．実測によるそよ風と人 工気流の性状比皎）、日本建築学会大会（近戴）学術講演梗概集（環境 工学) 、昭和62年 10 月、 pp. 343-344。

20 ）芥川郁雄・佐々太隆・林基哉・橋本直樹・荒谷登・赤木一郎 : 夏期の町 家に見られる㚆動気流下でのPMVの実測調查一開放型住居の体感指標 に関する研究 その 1 一、日本建築学会北海道支部研究報告焦、 No.60、昭和62年3月、pp.13-16。

2 1）大林勇・石田秀樹・荒谷登：空気温湿度・気流速変動からみた木影の㚘 やかさに関する研究、日本建築学会北海道支部研究報告集、No. 68 、 1995年3月、pp. 325-328。

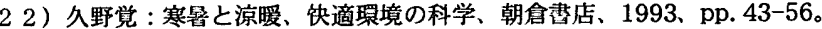

23 ) N. Baker: The Irritable Occupants : Recent Developments in Thermal Comfort Theory, Architectural Resarch Quarterly, Vol.2, Cambridge, 1996, pp. 84-90。

24 ) トランスナショナルカレッジ オブ レックス : フーリエの目険、言語 交流研究所 ヒッポファミリークラフ、1988。

25 ）北條厚子・裿绿倫実・斉藤雅也・宿谷昌則：『涼しさ』感に関する研究 その1.『涼しさ』感に関かる物理量、日本建築学会大会 (九州) 学街 講演梗概集（睘境工学II）、1998、pp. 451-452。

26 ）裙塚偷実・北條厚子・斉藤雅也・宿谷昌則：『涼しさ』感に関する研究 その 2. 僦しさ』感が得られる気流速度の㚆動の大きさ、日本建筮学 会大会（九州）学術讙演梗概集（環境工学II）、1998、pp.453-454。

（1998年 7 月 23 日原稿受理，1999年 3 月26日採用決定） 